
\title{
$\begin{array}{ll}\text { Research Square } & \begin{array}{l}\text { Preprints are preliminary reports that have not undergone peer review. } \\ \text { They should not be considered conclusive, used to inform clinical practice, } \\ \text { or referenced by the media as validated information. }\end{array}\end{array}$
}

\section{Exotic Tree Species Outnumbering Native Tree Species: an Alarming Situation for the Sustainable Urban Plantation Development}

\author{
Muhammad Umair Umair Shafique ( $\nabla$ umairhorti@yahoo.com ) \\ University of Agriculture Faisalabad \\ Adnan Younis \\ University of Agriculture Faisalabad Institute of Horticultural Sciences \\ Muhammad Asif \\ university of Agriculture Faisalabad \\ Mansoor Hameed \\ University of Agriculture, Faisalabad
}

\section{Research Article}

Keywords: Tree diversity, Faisalabad, Native, Exotic, Diversity indices, Species Richness.

Posted Date: December 13th, 2021

DOI: https://doi.org/10.21203/rs.3.rs-1079672/v1

License: (c) (i) This work is licensed under a Creative Commons Attribution 4.0 International License. Read Full License 


\section{Abstract}

This present study mainly focuses on the tree distribution and diversity of some selected roadsides in Faisalabad, a major city in Punjab, Pakistan. A total census of the tree population on selected roads was carried out and then studied for various parameters. Shannon-Wiener index, Reciprocal of Simpson's diversity index, and Shannon Evenness were among the different species diversity indices which were studied. Observational results showed that the selected roads in the city hold low tree diversity, with nearly 2858 trees of 34 species, 30 genera, and 15 families. Mainly exotic tree species dominated the plantation of selected roadsides. The topmost three species contributing approximately $60 \%$ of the tree population are Conocarpus erectus, Eucalyptus crebra, and Terminalia mantaly. Despite the dominance of exotic tree species, many native tree species are also growing along selected roadsides. Since, Faisalabad has been reported as one of the most polluted cities in the world due to high suspended particulate matter, appropriate efforts are needed to improve the plantation pattern and also to enhance the canopy of the trees in the city to minimize the problem of air pollution.

\section{1.introduction}

Roads are linear constructions that provide access to natural resources and link human populations. (Kollarou et al., 2013). Roads are an integral part of the transportation system. These systems of transportation cover enormous regions and are found throughout the majority of terrestrial ecosystems (Bennett, 1991). Roads have a significant influence on the neighboring environment. Roads lined with trees are regarded as attractive and appealing areas, and they are becoming a regular landscape feature in cities. Roadside habitats are distinct ecosystems that exist on unpaved ground adjacent to a road, such as median strips and road verges. Roadsides have been cited as novel ecosystems by several authors because they are derived by and are inextricably tied to human actions (Hobbs et al., 2006; García-Palacios et al., 2011; Jimenez et al., 2013; Auestad et al., 2016). They are susceptible to abiotic circumstances produced by humans, which may result in the formation of new communities (Hobbs et al., 2006). The roadside plantation is the first line of defense against city vehicular pollution. Trees have a critical function in decreasing air pollution and particulate matter. Trees purify the air by absorbing toxins via their leaf stomata. (Horaginamani et al., 2012).

Cities in developing countries are suffering from a rapid increase in the human population, and this has increased the social burden on the cities because of their low capacity to acclimatize with social and economic problems of novel environments. According to estimates, $50 \%$ of the world's population currently resides in $3 \%$ of the world's urbanized surface. (UN, 2016). Consequently, the environmental sustainability of towns and cities is becoming a growing concern. In this sense, urban greenery has been of particular attention since it delivers a variety of ecosystem services that are beneficial to human beings (Colding et al., 2006). It is essential for the preservation of biodiversity and supports diverse ecosystem components. (Jim and Chen, 2009). Urban biodiversity also allows its people to engage with nature, increasing awareness and understanding of the vital ecological, social, and psychological functions of green spaces. To provide this vast variety of ecosystem services, urban trees must withstand a stressful urban environment in order to mature. It is critical to select adaptable trees to ensure the durability of urban tree populations. (Sjöman et al. 2016). Nonetheless, selecting species suited to urban environments is seen as a difficult task. (Bassuk et al., 2002). According to certain research, native tree species have greater health than exotic ones since they are better adapted to local circumstances. (Garcia-Garcia et al., 2016).

A diverse range of species and genera has been recommended as a crucial approach for maintaining a sustainable and healthy urban tree population. (Bassuk, 1988). The most imperious and most common dispute over the elevated level of diversity is the frequent occurrence of invasive diseases and pests in frequently used tree species (Tello et al., 2005; Raupp et al., 2006). Barker (1975) firstly proposed the usage of a diverse variety of species. According to him, no single species accounts for more than $5 \%$ of the entire population of trees. Smiley et al. (1986) and Miller and Miller (1991) suggested that a single species should not have more than $10 \%$ of the tree population. Grey and Deneke (1986) also suggested the same viewpoint, arguing that no single species should have contributed more than 10-15 percent of the total tree population. In another study, Moll (1989) advises that a single specie contributes approximately $5 \%$ of the total tree population and no genus should exceed $10 \%$. Santamour (1990) broadens the rule as he aims at maximum usage of species and genera from the same family; a single species should not exceed more than $10 \%$ of the total population; in case of genera, $20 \%$ is the limit; and no family should exceed $30 \%$. Such species choice strategies are essential guides for a more diversified usage of tree species in the urban context. 
Trees have a vital role in creating landscapes by performing crucial ecological, social, and economic services as well as providing beauty to the human environment. (Nowak et al., 2006). Despite covering less than $3 \%$ of the worldwide terrestrial surface, cities account for over $3 / 4$ of carbon emissions and industrial wood demand, as well as roughly $60 \%$ of household water usage. (Singh et al., 2010).

Nonetheless, despite ample evidence of trees' important function in urban settings, urban planners and managers have frequently underestimated this role. When developmental projects, especially the widening of roads take place, it is customary practice to sacrifice roadside trees first, especially in rapidly developing cities. There is a need for data on tree census and several other elements for sustainable tree plantation along roadsides. (Maco and McPherson, 2003). The primary goals of this study were to collect information on tree distribution, species composition, diversity index, and tree density along various roadsides of Faisalabad which will help us to analyze the existing situation of the city roadside plantation.

\section{Materials And Methods}

2.1. Study site: The present investigation was carried out in Faisalabad, Punjab, Pakistan, at the coordinates $31^{\circ} 25^{\prime} 0^{\prime \prime} \mathrm{North}, 73^{\circ} 5^{\prime}$ 0" East (Fig. 1). Faisalabad is located 186 meters (610 feet) above sea level on the undulating flat plains of northeast Punjab. The city covers roughly 1,230 square kilometers ( $470 \mathrm{sq} \mathrm{mi).} \mathrm{The} \mathrm{River} \mathrm{Chenab} \mathrm{runs} \mathrm{approximately} 30$ kilometers (19 miles), whereas the Ravi River flows approximately 40 kilometers ( 25 miles) to the southeast. The lower Chenab canal serves as the primary source of irrigation for 80 percent of farmed fields. Faisalabad is bordered by Chiniot and Sheikhupura on the north, Sheikhupura and Sahiwal on the east, Sahiwal and Toba Tek Singh on the south, and Jhang on the west. Faisalabad's average temperature is $24.2^{\circ} \mathrm{C}\left(75.5^{\circ} \mathrm{F}\right)$. The annual rainfall is $346 \mathrm{~mm}$ (13.6 inches). Faisalabad City has changed tremendously in the past two decades, with various infrastructural development including the construction of office buildings, schools, residences, and roadways to meet the requirements of the ever-rising city's population.

2.2. Data collection and analysis: The research study focuses on some of the most notable roadside sites in Faisalabad City. Six main roadsides were chosen for this purpose, totaling $27.36 \mathrm{~km}$ and varying in length from $1.81 \mathrm{~km}$ to $6.55 \mathrm{~km}$. The entire study was based on a direct tree census, which was conducted in the survey area in 2020. Trees along roadsides were evaluated and counted up to a radius of 15 meters from the center of the road. Trees with DBHs of more than $10 \mathrm{~cm}(\mathrm{CBH}$ greater than $30 \mathrm{~cm}$ ) were evaluated.

2.2.1. Computation of Growth Parameters. The following growth parameters have been computed.

Basal Area. By using the following equation, the basal area of all trees was determined (Fuwape and Onyekwlu , 2011).

$$
\mathrm{BA}=\frac{\pi D^{2}}{4}
$$

where BA stands for basal area $\left(\mathrm{m}^{2}\right), \boldsymbol{D}$ represents diameter at breast height $(\mathrm{m})$, and $\Pi$ valued as (3.142). By summing the BA of all selected roadside trees, the total BA for the selected roadsides was determined.

Species Relative Density (RD). It is an indicator used for analyzing relative distribution of species (Brashears et al., 2004). Species Relative Density was calculated using the following equation:

$$
\mathrm{RD}=\frac{n_{i}}{N} \times 100
$$

where RD (\%) represents species relative density, $n_{i}$ counts the individuals of species $\mathrm{I}$, and $\mathrm{N}$ represents the count of total individual trees of all tree species along selected roadsides.

Species Relative Dominance (RDo). Species Relative Dominance (RDo), which is used to measure a tree's relative space occupancy, was calculated using (Aidar et al., 2001). 


$$
\mathrm{R} D_{O}=\frac{\left(\sum B a_{i} \times 100\right)}{\sum B a_{n}}
$$

where Bai represents the total basal area of all trees of a specific species I, and $\mathrm{Ba}_{n}$ represents the total basal area of all trees on selected roadsides.

Importance Value Index (IVI). The Importance Value Index (IVI) of each species was calculated using the equation below. (Brashears et al., 2004):

$$
\mathrm{IVI}=\frac{\left(R D+R D_{0}\right)}{2}
$$

\subsubsection{Species diversity indices and statistical computation}

A diversity index, in terms of numerical value, indicates the structure of a biological community. It typically provides more information regarding community diversity than merely species abundance. Furthermore, the diversity index can provide information about the commonness and rarity of species in an ecosystem, making it a significant tool for scientists in their understanding of ecosystems.

Simpson (Simpson, 1949), Shannon Evenness and Shannon-Wiener index (Lloyd et al.,1968) were selected as species diversity indicators. The Simpson index determines the probability that a second individual chosen from a population (vegetation community) will be of the same species as the first. The Shannon Evenness $\left(H_{E}\right)$ refers to the pattern of individual distribution among species. The Shannon-Wiener index measures a vegetative community's species heterogeneity.

Simpson's Index. Simpson's index of diversity is computed as:

$$
\mathrm{D}=\frac{\sum(\mathrm{n}-1)}{N(N-1)}
$$

Where, $\mathrm{N}$ represents the total number of tree species in an area and ' $\mathrm{n}$ ' represents the total number of a specific tree species. The reciprocal of Simpson's index was employed in this study to determine the tree diversity of a selected roadside.

Shannon Evenness. Shannon evenness was computed using the following formula::

$$
H_{E}=\frac{H}{\ln S}
$$

Where $\mathrm{H}$ represents the Shannon index and $\mathrm{S}$ represents the species richness

Shannon Index of Diversity. Shannon index of diversity $\left(\mathrm{H}^{\prime}\right)$ is used for quantifying biodiversity in a specific area, and it is computed as

$$
H^{\prime}=\sum_{i=1}^{s} P_{i} \operatorname{In}\left(P_{i}\right)
$$

where $\mathrm{N}$ represents the total number of tree species in an area and pi, represents the relative abundance of the ith species. The measure of this diversity index spans from 0 to infinity in principle, combines elements of species richness and evenness, and increases as the number of tree species increases. (Stohlgren, 2007).

Biomass Index. The biomass index is used to estimate the contribution of individual tree species to the treescape and the provision of services in an ecosystem. It is calculated as follows: 
$\mathrm{B}=\frac{\text { Tree count } \times \text { Final height Score }}{100}$

Where, trees of $(5-9 \mathrm{~m})$ height are small, $(9-18 \mathrm{~m})$ are medium, and $(>18 \mathrm{~m})$ are large tree species and scored as 1,2 , and 3 accordingly (Jim and Chen, 2009a).

Tree density. Tree density was estimated by using following equation:

Tree Density $=\frac{\text { No.of total tree Species }}{\text { Total length of roadside }(\mathrm{Km})}$

\section{Results}

\subsection{Species Richness and Diversity}

The findings of the current study showed the existence of 2858 trees belonging to 34 species, 30 genera, and 15 families along chosen roads in the city. The dominant species on the basis of numbers are Conocarpus erectus (1332), followed by Euclyptus crebra (205) and Terminalia mantaly (196). (Table 1). According to the findings, the species relative density (RD) of individual trees along chosen roadsides ranged from 0.03 to 46.60 percent (Table 1). Tree species with a high relative density (RD) were Conocarpus erectus, Eucalyptus crebra, and Terminalia mantaly, accounting for (46.60\%), (7.17\%), and (6.85\%) respectively, Species Relative Dominance (RDo) varied from 0.00005 to $15.10 \%$ (Table 1). Tree species with high relative dominance (RDo) were Conocarpus erectus, Eucalyptus crebra, and Azadirachta indica accounting for (15.10\%), (1.50\%), and (0.40\%) respectively. Tree species with the highest Importance Value Index were observed in Conocarpus erectus (30.8), followed by Eucalyptus crebra (4.33), and Terminalia mantaly (3.53\%) on the selected roadsides of Faisalabad. Maximum biomass index percentage was shown by C. erectus (50.60\%), followed by E. crebra (11.68\%), and T. mantaly (7.44\%). Out of all, these species account for $(69.72 \%)$ of the total biomass (Table 1$)$. Out of a total of 15 families to which tree species belong, both Fabaceae and Moraceae rank first with 6 species each, followed by Areaceae(4), Myrtaceae (3), Apocynaceae (3), Combretaceae (2), Meliaceae (2) and Boraginaceae, Bignoniaceae, Rhamnaceae, Lythraceae, Ulmaceae, Malvaceae, Papilionaceae, and Sapotaceae each with 1 species (Figure 1). The tree population along roadsides shows a diverse composition of species. Minor components are palms, which represent only (6.3\%) of the total tree species. Approximately (67.83\%) of the trees are evergreen broadleaved and (25.87\%) deciduous broadleaved. A total of 20 species belong to the deciduous broadleaved, 10 evergreen broadleaved and 4 palm species are present (Table 1). Among all the roadsides, maximum species richness was recorded at Narwala Road (24) while minimum species richness was recorded at Sargodha Road (12). The maximum number of trees was recorded at Narwala Road (570) while the minimum number of trees was recorded at Jhang Road (318). Maximum tree density was recorded at Qaim Sain Road (225.96 trees/km) while minimum tree density was recorded at Narwala Road (91.48 trees/km). (Table 2).

\subsection{Origin of the Species}

Out of the total tree species existing at chosen roadsides, 22 are native, and 12 are exotic species (Table 3). Native tree species contribute $26 \%$ of the total tree count, with $25.75 \%$ of attainable biomass. Exotic tree species contribute $74 \%$ of the total tree count, with $74.25 \%$ of attainable biomass. The results of the biomass index percentage reveal that the maximum biomass index percentage of native trees was recorded at Narwala Road (40.49\%) while the minimum biomass index of native trees was recorded at Sargodha Road (6.39\%). The maximum biomass index percentage of exotic trees was recorded at Sargodha Road (93.61\%) while the minimum biomass index percentage of exotic trees was recorded at Jhang Road (59.51\%). Maximum species richness of native trees was recorded at Narwala Road (16), while minimum species richness of native trees was recoded at Sargodha Road (9). Maximum species richness of exotic trees was recorded at Jail Road (9), while minimum species richness of exotic trees was recorded at Daewoo Road and Sargodha Road (4). A maximum number of native trees was recorded at Jail Road (210), while a minimum number of native trees was recorded at Sargodha Road (50). A maximum number of exotic trees was recorded at Sargodha Road (508) and a minimum number of exotic trees was recorded at Jhang Road (203). The maximum density of native trees was recorded at Qaim Sain Road (79 trees $/ \mathrm{km}$ ), while the minimum tree density of native trees was recorded at Sargodha Road (7.63 trees $/ \mathrm{km})$. The maximum tree density of exotic trees was recorded at Qaim Sain Road (146.96 trees $/ \mathrm{km})$, while the minimum tree density of exotic trees was recorded at Jhang Road (40.76 trees/km) (Table 2).

Page 5/16 


\subsection{Diversity Indices}

For the current study area, the Shannon-Weiner index $(\mathrm{H})$ varied from 0.52 to 2.56 , with an average of 1.68 . A maximum value of Shannon-Weiner index $(\mathrm{H})$ of 2.56 was calculated at Jail Road, followed by Jhang Road with ' $\mathrm{H}$ ' as 2.3. The least value of the Shannon-Weiner index $(H)$ of 0.52 was calculated at Sargodha Road. Shannon's evenness index $\left(H_{E}\right)$ varied from 0.21 to 0.80 with an average of 0.56 . Sargodha road has a minimum $H_{E}$ of 0.21 and Jail Road has the highest HE (0.80). Reciprocal Simpson's Index $(1 / D)$ varied from 1.23 to 10.14 with an average value of 5.17. Jail road had maximum value of 1/D (10.14) followed by Jhang road (6.79) while lowest value of 1/D (1.23) was calculated at Sargodha Road.

\section{Discussion}

Faisalabad is an old and important city in Pakistan. The current study is of great significance in that it provides knowledge of the diversity and distribution of urban trees present on the selected roadsides. No such work has been done in any part of Faisalabad before, so the current study is the first of its kind. Faisalabad's infrastructure and other industrial developments are progressing at a rapid pace. The environment of the city has become contaminated as a result of increased transportation and the sprouting of numerous other small industrial units within city limits. The air quality of Faisalabad city is deteriorating very rapidly due to the everincreasing pressure of industries and traffic. People in the region have complained of diseases such as coughing, throat pain, asthma, and other lung diseases as a result of the poor air quality. The current research can also be used by Faisalabad Municipal Corporation, Parks and Horticulture Authority, Faisalabad officials and other policymakers when forecasting possible threats to the population of local urban trees from the occurrence of severe pests and diseases, as well as how well an area is planned to cope with global warming and climate change in the future.

Species richness (34 species in 30 genera and 15 families) as observed in the current study is less than the species richness (53 species in 47 genera and 24 families) reported by (Bhat et al., 2016) on the roadside of Gwalior city, India. Our results also indicate a lower species diversity than that observed in the street trees of South Africa's Eastern Cape (Kuruneri-Chitepo and Shackleton, 2011), where approximately 1500 street trees of 61 species were recorded in three cities. Forests with higher levels of species diversity are considered to be superior than low species diversity forests (McPherson and Rowantree, 1989; Thaiutsa et al., 2008). (Lohbeck et al., 2016) reveal that ecosystems with a higher level of species diversity are more efficient, stable, and disaster-resistant as compared to those with lower species diversity, since a large number of species have a variety of characteristics that can contribute to different functions. The roadsides of Faisalabad city have lower tree diversity, as only the first four species, including Conocarpus erectus, Euclyptus crebra, Terminalia mantaly, and Thevetia peruviana contributed more than half of the total tree proportion of the area (65.3\%). C. erectus individually contributed $46.6 \%$ of the total tree proportion and ranked first in abundance. This shows that $C$. erectus is growing almost in a monoculture plantation pattern on the majority of selected roads. Researchers have criticized the single-species monocultural plantation pattern for allegedly having a number of harmful social and environmental consequences despite the documented benefits at economic level. (Erskine et al., 2006; Alem et al., 2015). Loss of soil fertility and productivity, disturbance of the water cycle, hazards related to practices of forestry plantation (e.g., exotic species introduction), dangers of helping diseases and pests, increased danger of extremely adverse storm and fire effects, and bad effects on biodiversity are just a few of the environmental consequences. (Baltodano, 2000; Evans, 2000; Bowyer, 2006). Thomson et al. (2016) in his study of street trees in 16 municipalities in Denmark, reported that genus Tilia individually contributed $26 \%$ of the total tree proportion in the study area.

On the roadsides of Faisalabad city, exotic species are present in greater adundance (78.4\%) than native ones (21.5\%). Our results agreed with those of Nowak (1993) and Nagendra and Gopal (2011). These researchers found that exotic species predominated in the urban woods of Oakland (USA) and Bangalore (India) by 69 and 77 percent, respectively. Further, Thomsen et al. (2016) recently reported the dominance of exotic species (71\%) in some 16 large Danish municipalities. However, Sanders (1981), Hobbs (1988) and Zipperer (2002) reported contrary results, $85 \%, 64 \%$, and $73 \%$ dominance of native species respectively for the Syracuse, St. Paul and Minneapolis areas of Minnesota, and Miami-Dade County of Florida, USA. Exotic tree species can also play a significant role in the ecosystem of the urban forest. The majority of existing species are urban exploiters in the urban environment, which may be found in urban locations all over the world. Furthermore, the value of some ecosystem services offered by exotic species is similar to, if not higher than, that offered by indigenous species. (Drayton and Primack, 1996). However, owing to continual competition between natives and exotics, urban woods are losing a substantial amount of their native species. The presence of a

Page 6/16 
higher number of exotic tree species along the roadsides of Faisalabad can result in an ecological imbalance of ecosystem services. One of the most significant challenges to natural ecosystems is invasive or exotic tree species. (Brundu and Richardson, 2016; Hejda et al., 2017). Due to species-specific effects on light availability (Niinemets, 2010; Dyderski et al., 2019) and nutrient cycling (Castro-Díez et al., 2014; Mueller et al., 2015), The functioning of invaded ecosystems is dramatically altered by alien tree species (Castro-Díez et al., 2019; Gentili et al., 2019). As a consequence, alien tree species influence dependent native organisms: soil microbes (Stanek and Stefanowicz, 2019), invertebrates (Mueller et al., 2016; Kohyt and Skubała, 2019), fungi (Dickie et al., 2010; Kałucka and Jagodzinski, 2016), bryophytes ( Woziwoda et al., 2017 ;Jagodzinski et al., 2018) and vascular plants (Taylor et al., 2016; Woziwoda et al., 2019; Šibíková et al., 2019). So, in light of our result there is a dire need to change the trend of our plantation, for this purpose all the managements involved in city plantations and city policy makers should renew their plan and strategy of plantation along the roadsides of Faisalabad to develop a sustainable plantation pattern. There should be more emphasis on the use of native trees in city landscape and to promote the awareness about native trees local government, research institutes, and nursery owners should play their role by highlighting the value and importance of native trees.

The average value of the Shannon index (1.686) as found in the present investigation did not fall under the range when related to the urban areas in the USA (2.1-3.9 range; 2.7 average) (McPherson and Rowantree, 1989); and Bangalore, India (2.68) (Nagendra and Gopal, 2010). Shannon's evenness index $\left(H_{E}\right)$ and Reciprocal Simpson's Index (1/D) have an average value of 0.56 and 5.17 respectively. These diversity indices evidently shows that the selected roadsides of Faisalabad City possess low tree species evenness and diversity. Our results are not in line with the study conduct in Gwalior city by (Bhat et al., 2016) who reported moderate value of diversity indices for roadside trees. Our results also conflict with the findings of Jim and Zhang (2013), who calculated the tree diversity of the roadsides of Hong Kong and reported a higher value of the diversity indices. The results of the present study are also contrary to those of Nagendra and Gopal (2010), who stated a moderate value of the Shannon-Weiner index in Bangalore for roadside trees. The current study of selected roadsides depicted that the first four tree species make a significant contribution (65.3 percent) to the total tree count, which results in reduced species evenness. All these four species, which make up about $65.3 \%$ of the tree community on different roadsides of Faisalabad, are exotic in nature. The dominance of exotic trees along roadsides is a serious threat to the sustainability of ecosystem functioning. Planting more native tree species could help to create biologically healthy urban forests along the roadsides, which will help not only humans but also improve the sustainability of urban ecosystems. A rich composition of species prevents the attack of pests on such species (Jim and Chen, 2009b). Wild life in the area may be attracted more when there is more species richness in the area.

\section{Conclusion}

During the study period, a total of 2858 trees of 34 species were noted at chosen roadside locations in Faisalabad City. The major tree species on the selected roads was $C$. erectus (46.6\%). The Combretacea family dominated the selected roadsides, accounting for $(53.54 \%)$ of the total tree population. All the selected roadsides of the city are mainly occupied by exotic tree species $(73.03 \%)$ like $C$. erectus, E. crebra , T. mantaly and T. peruviana. Native species have only (26.07\%) occupancy along the selected roadsides. $C$. erectus, being a hardy and easy to grow specie, is spreading very quickly in the city of Faisalabad. Many different exotic tree species in higher numbers are growing and needed to be carefully substituted by beneficial native tree species. The results depicted that tree diversity and diversity indices of selected roadsides are extremely less than required. By keeping in view, the findings of the present study and the literature of past studies, the government sector as well as private sectors involved in the plantation along the roads of the city of Faisalabad should emphasize the plantation of native trees in proper proportion and balance, which will ultimately help to improve the sustainable ecological functioning of the city.

\section{Declarations}

\section{Funding}

Not applicable

\section{Declaration of competing interest}

The authors declare that they have no known competing financial interest or personal relationships that could have appeared to influence the work reported in this paper. 


\section{Availability of data and material}

Not applicable

\section{Code availability}

Not applicable

\section{References}

1. Aidar, M. P., Godoy, J. R., Bergmann, J., \& Joly, C.A. (2001). Atlantic Forest succession over calcareous soil, Parque Estadual Tur 'Istico do Alto Ribeira-PETAR, SP. Revista Brasileira de Botânica, 24(4),455-469.

2. Alem, S., Pavlis, J., Urban, J., \& Kucera, J. (2015). Pure and mixed plantations of Eucalyptus camaldulensis and Cupressus lusitanica: their growth interactions and effect on diversity and density of undergrowth woody plants in relation to light. Open Journal of Forestry, 5(04), 375-385.

3. Auestad, I., Rydgren, K., \& Austad, I. (2016). Near-natural methods promote restoration of species-rich grassland vegetationrevisiting a road verge trial after 9 years. Restoration Ecology, 24(3), 381-389.

4. Baltodano, J. (2000). Monoculture forestry: a critique from an ecological perspective. Tree trouble: a compilation of testimonies on the negative impact of large-scale monoculture tree plantations prepared for the $6^{\text {th }}$ COP of the FCCC.

5. Barker, P. (1975). Ordinance control of street trees. Journal of Arboriculture, 1, 212-215.

6. Bassuk, N. L. (1988). Recommended urban trees. Urban Horticulture Institute. Department of Floriculture and Ornamental Hort. Cornell University, Ithaca, New York.

7. Bassuk, N. L., Trowbridge, P., \& Grohs, C. (2002). Visual similarity and biological diversity: street tree selection and design. In invited paper at the European Conference of the International Society of Arboriculture, OSLO. 18-21.

8. Bennett, A. F. (1991). Roads, roadsides and wildlife conservation: a review. Nature conservation 2: the role of corridors, Surrey Beatty and Sons, Chipping Norton, New South Wales, Australia, 99-118.

9. Bhat, A. A., Sharma, B. K., \& Jain, A. K. (2016). Diversity and composition of roadside tree species at a metropolitan city of India. Imperial Journal of Interdisciplinary Research, 2, 66-73.

10. Bowyer, J. L. (2006). Forest Plantations threatening or saving natural forests. Arborvitae, 31, 8-9.

11. Brashears, M. B., Fajvan, M.A., \& Schuler, T.M. (2004). An assessment of canopy stratification and tree species diversity following clearcutting in central Appalachian hardwoods. Forest Science, 50(1), 54-64.

12. Brundu, G., \& Richardson, D. M. (2016). Planted forests and invasive alien trees in Europe: A Code for managing existing and future plantings to mitigate the risk of negative impacts from invasions. Neobiota, 30(1075), 5-47.

DOI:10.3897/neobiota.30.7015

13. Castro-Díez, P., Godoy, O., Alonso, A., Gallardo, A., \& Saldaña, A. (2014). What explains variation in the impacts of exotic plant invasions on the nitrogen cycle? A meta-analysis. Ecology Letters, 17(1), 1-12.

14. Castro-Díez, P., Vaz, A. S., Silva, J. S., Van Loo, M., Alonso, Á., Aponte, C., \& Godoy, O. (2019). Global effects of non-native tree species on multiple ecosystem services. Biological Reviews, 94(4), 1477-1501.

15. Colding, J., Lundberg, J., \& Folke, C. (2006). Incorporating green-area user groups in urban ecosystem management. $A M B I O: A$ Journal of the Human Environment, 35(5), 237-244.

16. Dickie, I. A., Bolstridge, N., Cooper, J. A., \& Peltzer, D. A. (2010). Co-invasion by Pinus and its mycorrhizal fungi. New Phytologist,187(2), 475-484.

17. Drayton, B., \& Primack, R.B. (1996). Plant species lost in an isolated conservation area in metropolitan Boston from 1984 to 1993. Conservation Biology, 10, 30-39.

18. Dyderski, M. K., \& Jagodziński, A. M. (2019). Similar impacts of alien and native tree species on understory light availability in a temperate forest. Forests, 10(11), 951-958.

19. Erskine, P. D., Lamb, D., \& Bristow, M. (2006). Tree species diversity and ecosystem function: can tropical multi-species plantations generate greater productivity. Forest Ecology and Management, 233(2-3), 205-210.

Page 8/16 
20. Evans, J. (2000). Sustainability of productivity in successive rotations. In: Proceedings of the International Conference on Timber Plantation Development. pp. 7-9.

21. Fuwape, J. A., \& Onyekwelu, J. C. (2011). Urban forest development in West Africa: benefits and challenges. Journal of Biodiversity and Ecological Sciences, 1(1), 77-94.

22. Garcia-Garcia, M. J., Sánchez-Medina, A., Alfonso-Corzo, E., \& Garcia, C. G. (2016). An index to identify suitable species in urban green areas. Urban Forestry \& Urban Greening,16(2016), 43-49. https://doi.org/10.1016/j.ufug.2016.01.006

23. García-Palacios, P., Bowker, M. A., Chapman, S. J., Maestre, F. T., Soliveres, S., Gallardo, A., \& Escudero, A. (2011). Earlysuccessional vegetation changes after roadside prairie restoration modify processes related with soil functioning by changing microbial functional diversity. Soil Biology and Biochemistry, 43(6), 1245-1253.

24. Gentili, R., Ferrè, C., Cardarelli, E., Montagnani, C., Bogliani, G., Citterio, S., \& Comolli, R. (2019). Comparing negative impacts of Prunus serotina, Quercus rubra and Robinia pseudoacacia on native forest ecosystems. Forests, 10(10), 842-850.

25. Grey, G.W., \& Deneke, F.J. (1986). Urban Forestry, $2^{\text {nd }}$ edition. Wiley, New York.

26. Guo, Y., Gong, p., \& Amundson, R. (2003). Pedodiversity in the United States of America. Geoderma, 117(1-2), 99-115.

27. Hejda, M., Hanzelka, J., Kadlec, T., Štrobl, M., Pyšek, P., \& Reif, J. (2017). Impacts of an invasive tree across trophic levels: species richness, community composition and resident species' traits. Diversity and Distribution, 23(9), 997-1007.

28. Hitchmough, J.D. (2011). Exotic plants and plantings in the sustainable, design urban landscape. Landscape and Urban Planning, 100(4), 380-382.

29. Hobbs, E.R. (1988). Species richness of urban forest patches and implications for urban landscape diversity. Landscape Ecology, 1, 141-152.

30. Hobbs, R. J., Arico, S., Aronson, J., Baron, J. S., Bridgewater, P., Cramer, V. A., \& Zobel, M. (2006). Novel ecosystems: theoretical and management aspects of the new ecological world order. Global Ecology and Biogeography, 15(1), 1-7.

31. Horaginamani, S. M., Ravichandran, M., \& Kamdod, A. S. M. (2012). Air pollution tolerance of selected plant species considered for urban green belt development in Trichy. World J. of Environ. Biosci. 1(1), 51-54.

32. Jagodziński, A. M., Wierzcholska, S., Dyderski, M. K., Horodecki, P., Rusińska, A., Gdula, A. K., \& Kasprowicz, M. (2018). Tree species effects on bryophyte guilds on a reclaimed post-mining site. Ecology Engineering, 110, 117-127.

33. Jim, C.Y., \& Chen, W. Y. (2009a). Diversity and distribution of landscape trees in the compact Asian city of Taipei. Applied Geography, 29, 577-587

34. Jim, C. Y., \& Chen, W. Y. (2009b). Ecosystem services and valuation of urban forests in China. Cities, 26(4), 187-194.

35. Jim, C.Y., \& Zhang, H. (2013). Species diversity and spatial differentiation of old-valuable trees in urban Hong Kong. Urban Forestry and Urban Greening, 12, 171-182.

36. Jimenez, M. D., Ruiz-Capillas, P., Mola, I., Pérez-Corona, E., Casado, M. A., \& Balaguer, L.(2013). Soil development at the roadside: a case study of a novel ecosystem. Land Degradation \& Development. 24(6), 564-574.

37. Kalucka, I. L., \& Jagodzinski, A. M. (2016). Successional traits of ectomycorrhizal fungi in forest reclamation after surface mining and agricultural disturbances: A review. Dendrobiology, 76, 91-104.

38. Kent, M., \& Coker,P. (1992). Vegetation Description and Analysis: A Practical Approach, John Wiley \& Sons, Chichester, UK.

39. Kohyt, J., \& Skubała, P. (2020). Oribatid mite (Acari: Oribatida) communities reveal the negative impact of the red oak (Quercus rubra L.) on soil fauna in Polish commercial forests. Pedobiologia, 79, 150594. DOI:10.1016/j.pedobi.2019.150594

40. Kollarou, V., Lantitsou, A., Athanasopoulou, A., \& Kollaros, G. (2013). Impact of roads on ecological conditions. In Proceedings of the $4^{\text {th }}$ International Conference on Environmental Management, Engineering, Planning and Economics (CEMEPE) and SECOTOX Conference. Mykonos island, Greece.

41. Kuruneri-Chitepo, C., \& Shackleton, C. M. (2011). The distribution, abundance and composition of street trees in selected towns of the Eastern Cape, South Africa. Urban Forestry \& Urban Greening,10(3), 247-254.

42. Lloyd, H., Zar, J. H., \& Karr, J. R. (1968). On the calculation of information-theoretical measure of diversity. American Midland Naturalist,79, 257-272.

43. Lohbeck, M., Bongers, F., Martinez-Ramos, M., \& Poorter, L. (2016). The importance of biodiversity and dominance for multiple ecosystem functions in a human-modified tropical landscape. Ecology, 97(10), 2772-2779. 
44. Maco, S.E., \& McPherson, E.G. (2003). A practical approach to assessing structure, function and value of street tree populations in small communities. Journal of Arboriculture, 29, 84-97.

45. McPherson, E.G., \& Rowntree, R.A. (1989). Using structural measures to compare twenty-two U.S. tree population. Landscape Journal, 8, 13-23.

46. Miller, R.H., \& Miller, R.W. (1991). Planting survival of selected street tree taxa. Journal of Arboriculture, 17, 185-191.

47. Moll, G. (1989). Improving the health of the urban forest. In: G. Moll, \& S. Ebenreck (Eds.), A Resource Guide for Urban and Community Forests.(pp. 119-130).Washington.

48. Mueller, K. E., Eisenhauer, N., Reich, P. B., Hobbie, S. E., Chadwick, O. A., Chorover, J., \& Oleksyn, J. (2016). Light, earthworms, and soil resources as predictors of diversity of 10 soil invertebrate groups across monocultures of 14 tree species. Soil Biology and Biochemistry, 92, 184-198.

49. Mueller, K. E., Hobbie, S. E., Chorover, J., Reich, P. B., Eisenhauer, N., Castellano, M. J., \& Oleksyn, J. (2015). Effects of litter traits, soil biota, and soil chemistry on soil carbon stocks at a common garden with 14 tree species. Biogeochemistry, 123(3), 313-327.

50. Nagendra, H., \& Gopal, D. (2010). Street trees in Bangalore: density, diversity, composition and distribution. Urban Forestry and Urban Greening, 9, 129-137

51. Nagendra, H., \& Gopal, D. (2011). Tree diversity, distribution, history and change in urban parks: studies in Bangalore, India. Urban Ecosystems, 14, 211-223.

52. Niinemets, Ü. (2010). A review of light interception in plant stands from leaf to canopy in different plant functional types and in species with varying shade tolerance. Ecological Research, 25(4), 693-714.

53. Nowak, D. J., Hoehn III, R. E., Crane, D. E., Stevens, J. C., \& Walton, J. T. (2006). Assessing urban forest effects and values, Washington, DC's urban forest. Resource Bulletin NRS-. US Department of Agriculture, Forest Service, Northern Research Station, Pennsylvania, p. 24.

54. Nowak, D.J. (1993). Historical vegetation change in Oakland and its implications for urban forest management. Journal of Arboriculture, 19, 313-319.

55. Raupp, M.J., Cumming, M.J., \& Raupp, E.C. (2006). Street tree diversity in eastern North America and its potential for tree loss to exotic borers. Arboriculture and Urban Forestry, 32 (6), 297-304.

56. Sanders, RA. (1981). Diversity in the street trees of Syracuse, New York. Urban Ecology, 5, 33-43.

57. Santamour, F.S. (1990). Trees for urban planting: diversity, uniformity and common sense. In: Proceedings of the 7th Conference of the Metropolitan Tree Improvement Alliance, vol. 7, pp. 57-65

58. Šibíková, M., Jarolímek, I., Hegedüšová, K., Májeková, J., Mikulová, K., Slabejová, D., \& Medvecká, J. (2019). Effect of planting alien Robinia pseudoacacia trees on homogenization of Central European forest vegetation. Science of the Total Environment, $687,1164-1175$.

59. Simpson, E. H. (1949). Measurement of diversity. Nature,163-168

60. Singh, V. S., Pandey, D. N., \& Chaudhary, P. (2010). Urban forest and open green spaces- lesson for Jaipur. Occasional Paper No. 1/2010. Rajasthan State Pollution Control Board, Rajasthan.

61. Sjöman, H., Morgenroth, J., Sjöman, J. D., Sæbø, A., \& Kowarik, I. (2016). Diversification of the urban forest can we afford to exclude exotic tree species. Urban Forestry \& Urban Greening, 18(2016), 237-241.

62. Smiley, E.T., Kielbaso, J.J., \& Proffer, T.J. (1986). Maple disease epidemic in southeastern Michigan. Journal of Arboriculture, 12 (5), 126-128.

63. Stanek, M., \& Stefanowicz, A. M. (2019). Invasive Quercus rubra negatively affected soil microbial communities relative to native Quercus robur in a semi-natural forest. Science of the Total Environment, 696,1-11

64. Stohlgren, T.J. (2007). In: Measuring Plant Diversity: Lessons from the Field. Oxford University Press, New York.

65. Taylor, K. T., Maxwell, B. D., Pauchard, A., Nuñez, M. A., \& Rew, L. J. (2016). Native versus non-native invasions: similarities and differences in the biodiversity impacts of Pinus contorta in introduced and native ranges. Diversity and Distribution, 22(5), 578588.

66. Tello, M.-L., Tomalak, M., Siwecki, R., Gaper, J., Motta, E., \& Mateo-Sagasta, E. (2005). Biotic urban growing condition - threats, pests and diseases. In: Konijnendijk, C.C., Nilsson, K., Randrup, T.B., Schipperijn, J. (Eds.), Urban Forests and Trees. (pp. 325-

Page $10 / 16$ 
365). Berlin.

67. Thaiutsa, B., Puangchit, L., Kjelgren, R., \& Arunpraparut, W. (2008). Urban green space, street tree and heritage large tree assessment in Bangkok, Thailand. Urban Forestry and Urban Greening, 7, 219-229.

68. Thomsen, P., Buhler, O., \& Kristoffersen, P. (2016). Diversity of street tree populations in larger Danish municipalities. Urban Forestry and Urban Greening, 15, 200-210.

69. United Nations, (2016). Urbanization and Development: world cities report 2016. Nairobi, United Nations Human Settlements Programmme. http://wcr.unhabitat.org/wpcontent/uploads/sites/16/2016/05/WCR\%20FullReport2016.pdf_(accessed on 15 March 2021).

70. Woziwoda, B., Dyderski, M. K., \& Jagodziński, A. M. (2019). Effects of land use change and Quercus rubra introduction on Vaccinium myrtillus performance in Pinus sylvestris forests. Forest Ecology and Management, 440, 1-11.

71. Woziwoda, B., Staniaszek-Kik, M., \& Stefańska-Krzaczek, E. (2017). Assemblages of native bryophytes in secondary forests with introduced Quercus rubra. Nordic Journal of Botany, 35(1), 111-120.

72. Zipperer, W.C. (2002). Species composition and structure of regenerated and remnant forest patches within an urban landscape. Urban Ecosystems, 6, 71-290.

\section{Tables}

Table 1. Diversity and distribution of tree species along some selected roadsides of Faisalabad 


\begin{tabular}{|c|c|c|c|c|c|c|c|c|c|c|}
\hline Rank & $\begin{array}{l}\text { TREE } \\
\text { SPECIES }\end{array}$ & FAMILY & ORIGIN & $\begin{array}{l}\text { NO } \\
\text { OF } \\
\text { TREE }\end{array}$ & $\begin{array}{l}\text { B.A } \\
\left(\mathrm{m}^{2}\right)\end{array}$ & R.D & R.DQ & IVI & $\begin{array}{l}\text { BIOMASS } \\
\text { INDEX } \\
\text { PERCENTAGE }\end{array}$ & $\begin{array}{l}\text { GROWTH } \\
\text { FORM }\end{array}$ \\
\hline 1 & $\begin{array}{l}\text { Conocarpus } \\
\text { erectus }\end{array}$ & Combretaceae & Exotic & 1332 & 31146.9 & 46.6 & 15.1 & 30.8 & 50.60 & BLE \\
\hline 2 & $\begin{array}{l}\text { Eucalyptus } \\
\text { crebra }\end{array}$ & Myrtaceae & Exotic & 205 & 3099.5 & 7.17 & 1.50 & 4.33 & 11.68 & BLE \\
\hline 3 & $\begin{array}{l}\text { Terminalia } \\
\text { mantaly }\end{array}$ & Combretaceae & Exotic & 196 & 488.8 & 6.85 & 0.21 & 3.53 & 3.92 & BLD \\
\hline 4 & $\begin{array}{l}\text { Thevetia } \\
\text { peruviana }\end{array}$ & Apocynacecae & Exotic & 134 & 113.5 & 4.68 & 0.05 & 2.37 & 2.64 & BLE \\
\hline 5 & $\begin{array}{l}\text { Ficus } \\
\text { binnendijkii }\end{array}$ & Moraceae & Native & 120 & 169 & 4.19 & 0.08 & 2.14 & 2.20 & BLE \\
\hline 6 & $\begin{array}{l}\text { Azadirachta } \\
\text { indica }\end{array}$ & Melliaceae & Native & 92 & 843.7 & 3.21 & 0.40 & 1.81 & 3.49 & BLD \\
\hline 7 & $\begin{array}{l}\text { Polyalthia } \\
\text { longifolia }\end{array}$ & Fabaceae & Native & 91 & 50.14 & 3.18 & 0.02 & 1.60 & 1.72 & BLE \\
\hline 8 & $\begin{array}{l}\text { Bismarckia } \\
\text { nobilis }\end{array}$ & Arecaceae & Exotic & 70 & 123.88 & 2.44 & 0.06 & 1.25 & 1.32 & PALM \\
\hline 9 & Morus alba & Moraceae & Native & 60 & 165.6 & 2.09 & 0.08 & 1.08 & 1.13 & BLD \\
\hline 10 & $\begin{array}{l}\text { Cebia } \\
\text { speciosa }\end{array}$ & Malvaceae & Exotic & 52 & 43.66 & 1.81 & 0.02 & 0.92 & 0.98 & BLD \\
\hline 11 & $\begin{array}{l}\text { Phoenix } \\
\text { dactyliferia }\end{array}$ & Arecaceae & Native & 50 & 208.5 & 1.74 & 0.10 & 0.92 & 0.89 & PALM \\
\hline 12 & Ficus Virens & Moraceae & Native & 48 & 103.06 & 1.67 & 0.05 & 0.86 & 1.82 & BLD \\
\hline 13 & $\begin{array}{l}\text { Livistona } \\
\text { chinensis }\end{array}$ & Areaceae & Exotic & 44 & 76.70 & 1.53 & 0.03 & 0.78 & 0.83 & PALM \\
\hline 14 & $\begin{array}{l}\text { Dalbergia } \\
\text { sissoo }\end{array}$ & Fabaceae & Native & 36 & 105.4 & 1.25 & 0.05 & 0.65 & 1.36 & BLD \\
\hline 15 & $\begin{array}{l}\text { Callistemon } \\
\text { Lanceolatus }\end{array}$ & Myrtaceae & Exotic & 35 & 15.48 & 1.22 & 0.007 & 0.61 & 0.66 & BLD \\
\hline 16 & $\begin{array}{l}\text { Alstonia } \\
\text { scholaris }\end{array}$ & Apocynacecae & Native & 34 & 16.63 & 1.18 & 0.008 & 0.59 & 1.29 & BLE \\
\hline 17 & $\begin{array}{l}\text { Melia } \\
\text { azedarach }\end{array}$ & Meliaceae & Native & 33 & 91.8 & 1.15 & 0.04 & 0.59 & 0.62 & BLD \\
\hline 18 & $\begin{array}{l}\text { Ficus } \\
\text { religiosa }\end{array}$ & Moraceae & Native & 29 & 87.3 & 1.01 & 0.04 & 0.52 & 1.10 & BLD \\
\hline 19 & $\begin{array}{l}\text { Ziziphus } \\
\text { mauritiana }\end{array}$ & Rhamnaceae & Native & 29 & 47.7 & 1.01 & 0.02 & 0.51 & 1.10 & BLD \\
\hline 20 & $\begin{array}{l}\text { Cassia } \\
\text { fistula }\end{array}$ & Fabaceae & Native & 25 & 15.48 & 0.87 & 0.007 & 0.44 & 0.94 & BLD \\
\hline 21 & $\begin{array}{l}\text { Pongamia } \\
\text { pinnata }\end{array}$ & Papilionaceae & Native & 22 & 5.19 & 0.76 & 0.002 & 0.38 & 0.41 & BLD \\
\hline 22 & $\begin{array}{l}\text { Tabebuia } \\
\text { aurea }\end{array}$ & Bignoniaceae & Exotic & 20 & 0.50 & 0.69 & 0.0002 & 0.35 & 0.37 & BLD \\
\hline 23 & $\begin{array}{l}\text { Syzygium } \\
\text { cumini }\end{array}$ & Myrtaceae & Native & 19 & 22.5 & 0.66 & 0.01 & 0.33 & 0.72 & BLD \\
\hline 24 & $\begin{array}{l}\text { Acacia } \\
\text { nilotica }\end{array}$ & Fabaceae & Native & 18 & 20.45 & 0.62 & 0.009 & 0.31 & 0.68 & BLD \\
\hline
\end{tabular}




\begin{tabular}{|llllllllllll}
25 & $\begin{array}{l}\text { Roystonea } \\
\text { regia }\end{array}$ & Arecaceae & Exotic & 17 & 7.14 & 0.59 & 0.003 & 0.29 & 0.96 & PALM \\
\hline 26 & $\begin{array}{l}\text { Ficus } \\
\text { benghalensis }\end{array}$ & Moraceae & Native & 14 & 20.84 & 0.48 & 0.010 & 0.24 & 0.79 & BLE \\
\hline 27 & $\begin{array}{l}\text { Holoptelea } \\
\text { integrifolia }\end{array}$ & Ulmaceae & Native & 7 & 8.84 & 0.24 & 0.004 & 0.12 & 0.39 & BLD \\
\hline 28 & $\begin{array}{l}\text { Albizia } \\
\text { lebbeck }\end{array}$ & Fabaceae & Exotic & 6 & 1.75 & 0.20 & 0.0008 & 0.10 & 0.22 & BLD \\
\hline 29 & $\begin{array}{l}\text { Bauhinia } \\
\text { variegate }\end{array}$ & Fabaceae & Native & 5 & 1.03 & 0.17 & 0.0005 & 0.08 & 0.09 & BLD \\
\hline 30 & $\begin{array}{l}\text { Ficus } \\
\text { benjamina }\end{array}$ & Moraceae & Native & 4 & 3.52 & 0.13 & 0.0001 & 0.07 & 0.07 & BLE \\
\hline 31 & $\begin{array}{l}\text { Plumeria } \\
\text { rubra }\end{array}$ & Apocynaceae & Exotic & 4 & 0.21 & 0.13 & 0.0001 & 0.07 & 0.07 & BLD \\
\hline 32 & $\begin{array}{l}\text { Cordia } \\
\text { sinensis }\end{array}$ & Boraginaceae & Native & 3 & 0.70 & 0.10 & 0.0003 & 0.05 & 0.11 & BLE \\
\hline 33 & $\begin{array}{l}\text { Mimusops } \\
\text { elengi }\end{array}$ & Sapotaceae & Native & 3 & 0.50 & 0.10 & 0.0002 & 0.05 & 0.11 & BLE \\
\hline 34 & $\begin{array}{l}\text { Punica } \\
\text { granatum }\end{array}$ & Lythraceae & Native & 1 & 0.01 & 0.03 & 0.00005 & 0.01 & 0.01 & BLD \\
\hline \begin{tabular}{l} 
Total \\
\hline 3
\end{tabular}
\end{tabular}

Table 2. Diversity indices of the selected roadsides of Faisalabad

\begin{tabular}{llllllll} 
Diversity Indices & $\begin{array}{l}\text { Jail } \\
\text { Road }\end{array}$ & $\begin{array}{l}\text { Saint Qaim } \\
\text { Road }\end{array}$ & $\begin{array}{l}\text { Narwala } \\
\text { Road }\end{array}$ & $\begin{array}{l}\text { Daewoo } \\
\text { Road }\end{array}$ & $\begin{array}{l}\text { Sargodha } \\
\text { Road }\end{array}$ & $\begin{array}{l}\text { Jhang } \\
\text { Road }\end{array}$ & Average \\
\hline Shannon Weiner index (H) & 2.56 & 1.69 & 2.2 & 0.85 & 0.52 & 2.3 & 1.68 \\
\hline Shannon Evenness (E) & 0.80 & 0.58 & 0.71 & 0.30 & 0.21 & 0.79 & 0.56 \\
\hline $\begin{array}{l}\text { Reciprocal Simpson's index } \\
(1 / \mathrm{D})\end{array}$ & 10.14 & 5.58 & 5.84 & 1.44 & 1.23 & 6.79 & 5.17 \\
\hline
\end{tabular}

Table 3.Species Richness and tree density of some selected roadsides of Faisalabad 


\begin{tabular}{|c|c|c|c|c|c|c|c|c|}
\hline Road Name & $\begin{array}{l}\text { Area } \\
(\mathrm{KM})\end{array}$ & Origin & $\begin{array}{l}\text { Species } \\
\text { Richness }\end{array}$ & $\begin{array}{l}\text { Tree } \\
\text { count }\end{array}$ & dbh(inches) & $\begin{array}{l}\text { Tree Frequency } \\
\% \text { age }\end{array}$ & $\begin{array}{l}\text { Tree } \\
\text { Density }\end{array}$ & $\begin{array}{l}\text { Biomass index } \\
\text { \%age }\end{array}$ \\
\hline \multirow[t]{2}{*}{ Jail road } & \multirow[t]{2}{*}{3.13} & Native & 15 & 210 & 3902.5 & 44.96 & 67.09 & 26.9 \\
\hline & & Exotic & 9 & 257 & 6100 & 55.04 & 82.10 & 73.1 \\
\hline Total & & & 24 & 467 & 10002.5 & 100 & 149.19 & 100 \\
\hline \multirow{2}{*}{$\begin{array}{l}\text { Qaim Saint } \\
\text { Road }\end{array}$} & \multirow[t]{2}{*}{1.81} & Native & 14 & 143 & 4498 & 34.9 & 79 & 37.2 \\
\hline & & Exotic & 4 & 266 & 5138 & 65.1 & 146.96 & 62.08 \\
\hline Total & & & 18 & 409 & 9636 & 100 & 225.96 & 100 \\
\hline \multirow{2}{*}{$\begin{array}{l}\text { Narwala } \\
\text { Road }\end{array}$} & \multirow[t]{2}{*}{6.23} & Native & 16 & 185 & 6121 & 32.45 & 29.69 & 40.49 \\
\hline & & Exotic & 6 & 385 & 7814 & 67.55 & 61.67 & 59.51 \\
\hline Total & & & 22 & 570 & 13935 & 100 & 91.48 & 100 \\
\hline \multirow{2}{*}{$\begin{array}{l}\text { Daewoo } \\
\text { Road }\end{array}$} & \multirow[t]{2}{*}{4.66} & Native & 12 & 81 & 2174 & 15.17 & 17.38 & 10.24 \\
\hline & & Exotic & 4 & 453 & 6957.5 & 84.83 & 97.21 & 89.76 \\
\hline Total & & & 16 & 534 & 9131.5 & 100 & 114.5 & 100 \\
\hline \multirow{2}{*}{$\begin{array}{l}\text { Sargodha } \\
\text { Road }\end{array}$} & \multirow[t]{2}{*}{6.55} & Native & 9 & 50 & 1461 & 8.96 & 7.63 & 6.39 \\
\hline & & Exotic & 3 & 508 & 12122 & 91.04 & 77.55 & 93.61 \\
\hline Total & & & 12 & 558 & 13583 & 100 & 85.18 & 100 \\
\hline \multirow[t]{2}{*}{ Jhang Road } & \multirow[t]{2}{*}{4.98} & Native & 13 & 115 & 3360 & 36.16 & 23.09 & 36.05 \\
\hline & & Exotic & 6 & 203 & 3681 & 63.84 & 40.76 & 63.95 \\
\hline Total & 27.36 & & 19 & 318 & 7041 & 100 & 63.85 & 100 \\
\hline
\end{tabular}

Figures 


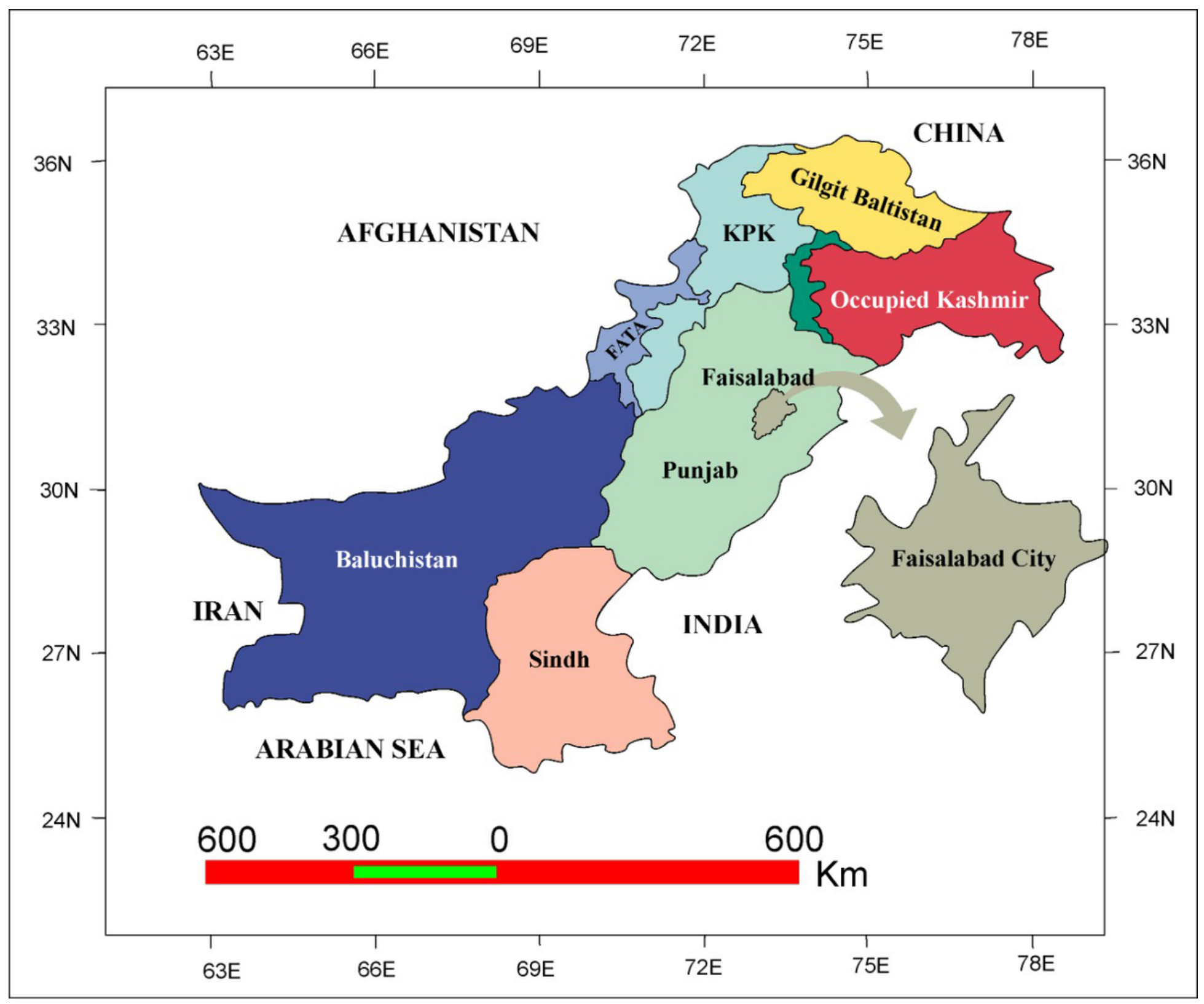

Figure 1

Map of Study Area
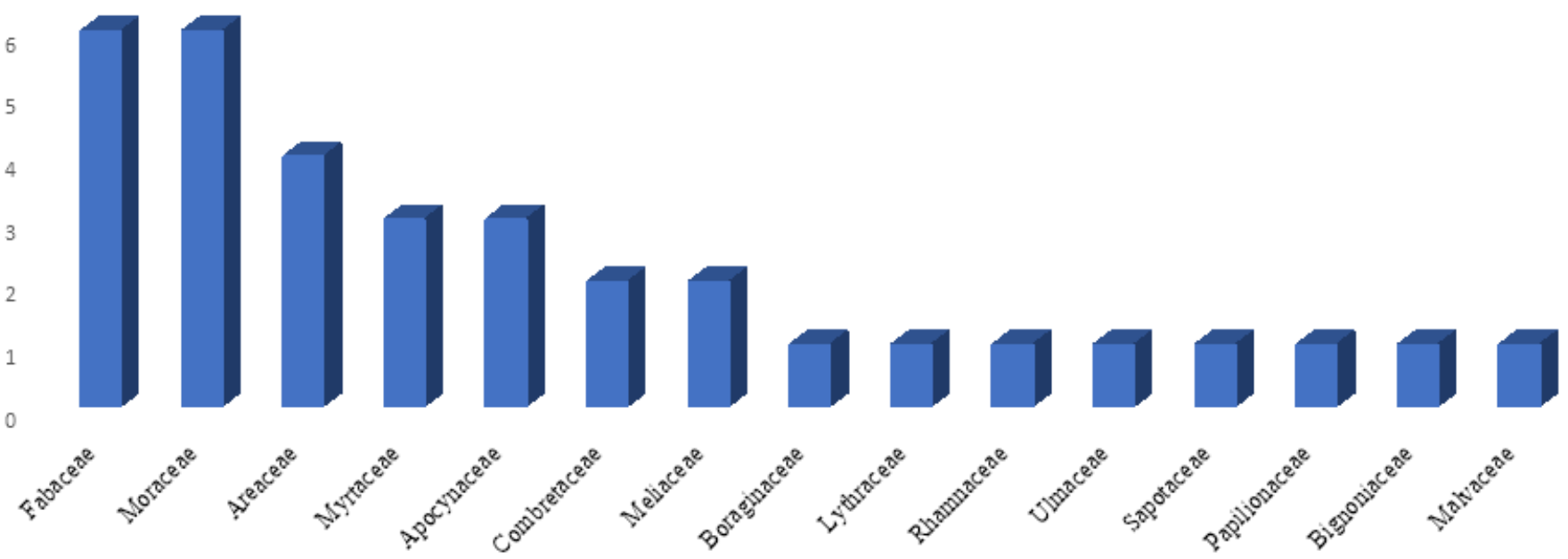
Figure 2

Diversity of different families along the selected roads of Faisalabad

Page 16/16 